https://dx.doi.org/10.4314/iijikm.v10i2.1

\title{
Strategic Framework for Service Delivery Improvement in School Libraries
}

\author{
Liah Shonhe \\ Faculty of Management \& Economics \\ Dalian University of Technology \\ Liaoning province, China \\ lmachara@yahoo.com \\ Evelyn M. Marambe \\ Department of Library \& Information Studies \\ University of Botswana \\ evelynmarambe@yahoo.com
}

\begin{abstract}
One of the fundamentals to building a knowledge-based economy is through the provision of quality information via school libraries. Schools play a fundamental role in raising an educated and informed nation. Therefore, the school library is fundamental to the teaching and learning activities of the school. The school library should be able to provide resources that are relevant to the school curriculum and also be able to provide quality information services to both students and teachers. That being said, this study introduces a school library assessment model that can be used by school management and librarians to evaluate the effectiveness of their school library resources and services. The proposed model integrates the IFLA school library guidelines and the LibQUAL model. The study is based on literature review to explicitly present the proposed model. The proposed school library assessment model is expected to help school librarians to implement the right programs and acquire the right resources for the school library, to be able to meet the users` information needs and satisfy them, thereby making the library relevant to the $21^{\text {st }}$ century information era. This will further ensure that the school library is rightly positioned to support training and teaching activities effectively. As a result, quality education and lifelong learning skills will be realized.
\end{abstract}

Keywords: School libraries, LibQUAL, quality, service, service delivery framework,

\section{Introduction}

A school library is a resource centre located within a school where teachers and students have access to a variety of information resources. According to Library Research

Service (2014, para 3) a school library is

"a dedicated facility located in and

administered by the school that provides at least the following: an organized, circulating collection of printed and/or audiovisual and/or computer-based resources, or a combination thereof; paid staff; an established schedule during which services of the staff are available to students and faculty; instruction on 
using library materials to support classroom standards and improve student research and literacy skills."

A school library is a place where sustaining literacy, self-education and lifelong learning is inculcated and nurtured to children, pupils and students. Mkumbo (2016) concurs that, using libraries enable people to get opportunities to learn and educate themselves in various aspects related to their daily life as well as building knowledge and understanding of the world, making informed decisions and consequently working productively in solving problems. Therefore, a school library is paramount to the learning and teaching activities of any school as it acts as an information hub and an innovation centre. Some of the roles and functions of a school library include; promoting a culture of reading and enhancing information literacy skills; providing a place for collaborative learning and creativity; supporting all educational programs and the

\section{Literature review}

This section provides a discussion on the challenges faced by school libraries. In addition, a discussion of the IFLA guidelines and LibQUAL model is provided here, as they form the basis for the proposed strategic framework. The content on this school curriculum; and provide teachers with access to proffessional development materials (Ashikuzzaman, 2013; Queensland Government, 2014; School Library Association, 2016). Helgren and Lance (2010) asserts that school libraries have a huge impact on student achievement. Thus they cannot afford to be ignored in the teaching and learning process.

Mkumbo (2016) stresses that education can be acquired from school libraries to help people become literate, be able to numerate, become problem solvers and achieve self actualization, economic sufficiency, civic responsibility and satisfactory human relationships. Libraries are gateways to knowledge and have a great role in supporting sustainable development. As a result, it is vital for school libraries to continously be evaluated to ensure that quality services are provided. Consequently, this will increase information access and improve the quality of learning.

section is based on literature review and researchers' experience/observation.

\section{Challenges Faced by School Libraries}

The motivation for this paper stemmed from the various challenges observed and experienced by the researchers' during their 
school library projects and through work experience. In various government senior secondary schools in Botswana, the researchers observed that the school library building is usually smaller, has uncatalogued books, lack of computers and internet, insufficient budget, has outdated and insufficient books. In some instances, some schools did not have a proper library building rather they had small classrooms which were used for storing books. One teacher librarian who plays a double role as a subject teacher and a librarian usually manages the school library. This has resulted in the library work suffering as the teachers are more focused on the teaching role more than the librarianship role. As a result, the teachers and students do not fully benefit from the school library services as it is under staffed and the opening times are limited and controlled by the availability of a teacher librarian (inaccessible opening hours). These observations correspond with what has been revealed in the literature. For example; according to a report by Boelens (2012) published on behalf of the International Association of School Librarianship (IASL); it was revealed that school libraries in developing countries are facing the following problems;

- Books and information in the students' mother tongue are unavailable.

- There is no central accommodation which provides access to books, information, audio-visual materials, other media, and reliable Internet access.

- Lack of electricity.

- People who run school libraries are often teachers, parents, volunteers and sometimes the children themselves, who have received various levels of (or virtually no) training in library and information science.

- Some school library collections are inadequate with insufficient books for all the students in the school; books are often outdated, old and dirty.

- Some schools do not have a room or special space for the school library.

Similarly, a study conducted in South Africa by Paton-Ash and Wilmot (2015) revealed that there was no national policy for school libraries in South Africa. Thus, there was nothing to compel school governing bodies and principals to have a library in their schools. Mojapelo (2016) affirmed that in South Africa, providing schools with a well-resourced and well- 
staffed library and information service is even more challenging because of the inheritance of the apartheid education system prior to 1994. Agyekum and Filson (2012) also found that despite the new educational reforms in Ghana, the school library is still facing some challenges such as; untrained library staff, poor funding and poor facilities among others. It is very clear in literarture that school libraries are facing various challenges which impact on students academic achievement and this hinders achievement of some of the SDGs. Our main contention is that school libraries are being ignored and not adequately resourced as they should be. As a result, they are not playing an effective role in supporting and enabling quality education. This results in poor service provision to students and teachers. Based on this premise, the researchers propose a model that will help school management and the government to assess the effectiveness of the school library resources and services. It is hoped that with this framework, service delivery can be improved in school libraries. The proposed model combines the constructs from IFLA school library guidelines and the LibQUAL model. The two models are explained below.

\section{IFLA School Library Guidelines}

Principles and guidelines are necessary for guiding the operation of theschool library as well as directing the management in the running of the library. There is need for a universal or standardized way of managing school libraries as they have the same goals. IFLA took the mantle for guiding and standardizing school library management across the world. The first edition of the school library guidelines was developed in 2002 by the School Libraries Section (IFLA School Libraries Section Standing Committee, 2015). IFLA Section of School Libraries published the second edition of the IFLA/UNESCO School Library Guidelines in 2015. This was edited by Barbara Schultz and Dianne Oberg, the project draws on the contributions from a wide international library community, hence making it more applicable in diverese settings. IFLA guidelines were developed to support school library professionals and educational decision-makers in their efforts to ensure that all students and teachers have access to effective school library programs and services, delivered by qualified school library personnel (IFLA School Libraries Section Standing Committee, 2015). The guidelines cover a wide range of areas within school librarianship and also provide evaluation checklists. The checklists can be used by school library stakeholders to 
improve school library programs; enhance the teaching and learning environment. As shown in Figure 1, IFLA school library guidelines covers all the necessary areas that need to be well managed in order to achieve the goals of the school library and ensure that it supports the school curriculum.

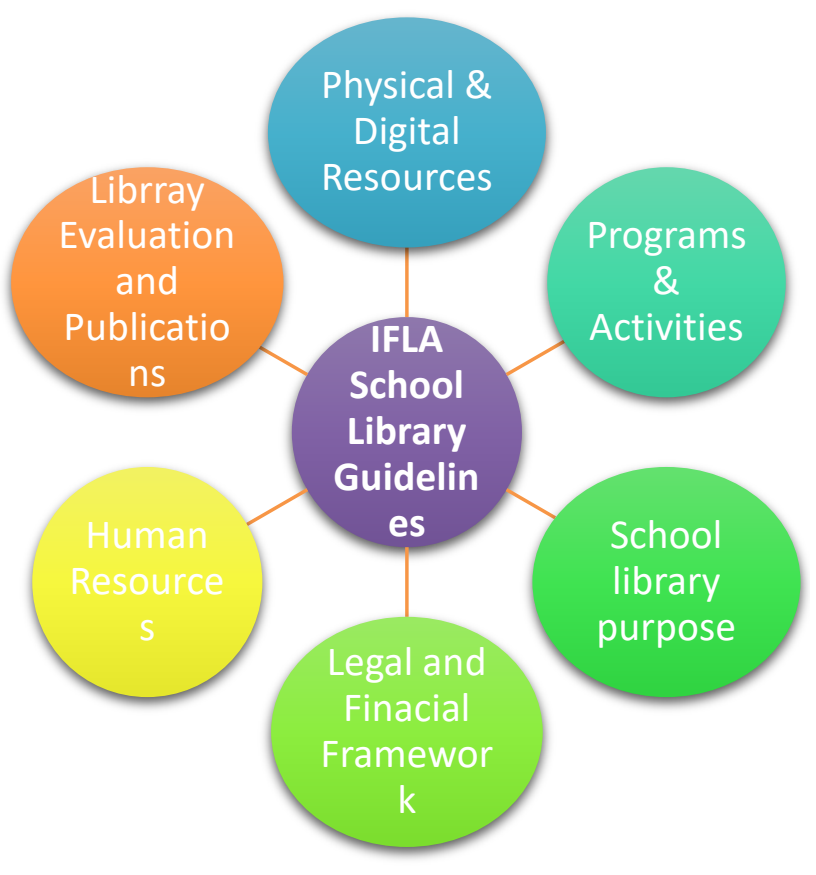

Figure 1: IFLA School Guidelines Categories.

Areas covered in the IFLA school library guidelines are discussed as follows:

a) Mission and Purpose of a School Library: The mission is a definition of the nature, purpose, and role of the school library as part of the school's shared purpose and commitment. "The mission and purpose of the school library should be stated clearly in terms that are consistent with the principles of the IFLA/UNESCO School Library Manifesto and the values expressed in the United Nations Declaration of the Rights of the Child, the United Nations Declaration on the Rights of Indigenous People, and in the Core Values of IFLA" (IFLA School Libraries Section Standing Committee, 2015, p.10) The guidelines posits that school libraries should have a clear mission statement. This would help the management to evaluate whether they are achieving their goals or not. In addition the school library should also have a vision statement which projects the future state desired for a school library. The vision should incorporate the five key trends identified in the IFLA Trend Report (2013):

1) New technologies will both expand and limit who has access to information.

2) Online education will democratize and disrupt global learning.

3) The boundaries of privacy and data protection will be redefined.

4) Hyper-connected societies will listen to and empower new voices and groups.

5) The global information economy 
will be transformed by new technologies.

\section{b) Legal and Finacial Framework of a} School Library: the school library should stiipulate all the regualtory and legal frameworks in which it operates in or adheres to. This will ensure that qualiity library services are provided to both teachers and learners. Examples of scuh legal or ethical considerations include but not limited to: Library Bill of Rights, Freedom of information and privacy, Statements of copyright, intellectual property and plagiarism, Rights of the Child and Rights of Indigenous People. Furthermore, a school library should be managed within a clearly structured policy framework that recognizes the library as a core resource and centre for reading and inquiry (IFLA School Libraries Section Standing Committee, 2015). According to the IFLA school library guidelines, the school library policy should stipulate the role of the library in relation to the following components:

- Formal and informal curriculum in the school

- Learning methods in the school

- National and local standards and criteria

- Learning and personal development needs of students

- Needs of teachers

- Raising levels of academic achievement

- Developing inquiry skills

- Promoting and motivating reading

c) Human Resource for a School Library: in order to effectively facilitate the teaching and learning process, the school library program needs to be under the direction of professional staff with the same level of education and preparation as classroom teachers (IFLA School Libraries Section Standing Committee, 2015). The school librarian takes the leadership role while trained clerical and technical support staff takes care of operational aspects of a school library. Some of the roles of a professional school librarian are; program management, instructional design and delivery, community engagement, leadership and collaboration, promoting library programs and services. Having documented competencies and roles of school library staff, helps the management to evaluate if the library 
staff meet the requirements and adheres to ethical standards. As a result, school library services effectiveness will be improved. Various school libraries impact studies conducted in the USA and UK shows that well-resourced school libraries staffed with professional school librarians enhances student achievement (Library Research Services, 2015; Williams, Wavell, \& Morrison, 2013).

d) Physical and Digital Resources of a School Library: "The physical and digital resources of a school library include facilities, equipment, and collections of resources for teaching and learning. Increasingly, technology extends the reach of a school library into the school as a whole and into the community...The facilities, equipment, and collections of a school library need to evolve in response to changes in the teaching and learning needs of the students and the teachers" (IFLA School Libraries Section Standing Committee, 2015 , p. 32). It is crucial to have up-todate technologies as they facilitate $24 / 7$ access to school library resources and to resources beyond the school day and beyond the school calendar. This ubiquitous access to information promotes and enhances the teaching and learning activities of the school. Therefore, it is necessary to constantly evaluate the effectiveness of the technologies implemented in a school library. The assessment should also consider the physical environment i.e. the physical space and facilities available.

\section{e) Programs and Activities of a School}

Library: A school library can achieve its mission and goals through wellresearched programs of instructional and service activities. School library programs should be aligned to the goals of the school and the needs of the broader community. "Services and activities must be designed by a qualified school librarian, working in close cooperation with the principal or head teacher, with heads of departments and other learning specialists in the school, with classroom teachers, with support staff, and with students." (IFLA School Libraries Section Standing Committee, 2015, p.39). This approach will ensure that the library programs are designed for the right clientele hence improve service quality. According to Reed 
(2016) one of the key elements to include in the school liibrary program is information literacy (IL) and inquiry based learning. The report further shows that various many countries, including Australia, New Zealand, South Africa, Scotland and Wales, have incorporated an information literacy framework of skills into their national educational programmes

a) School Library Evaluation and Public Relations: evaluation helps to ensure that the library's programs and services support the goals of the school. Evaluation of school library services and programs is an essential aspect of school library development. Unfortunately, school libraries and school librarians are rarely evaluated in a consistent and systematic way (IFLA School Libraries Section Standing Committee, 2015). Evaluation also serves accountability purposes: It helps to determine if the school library services and programs are meeting the needs of the school community. School library evaluation can be conducted based on the following approaches/perspectives; program quality, stakeholder perceptions, program content, program impact and evidence-based practice.

\section{LibQUAL Model}

LibQUAL is an instrument that helps to easily identify service quality from the customer perspective (Rehman, 2012). More than 1.5 million library users from twelve hundred libraries have participated in LibQUAL since its inception (Rehman, Kyrillidou, \& Hameed, 2014). LibQUAL was a research project developed in collaboration between the Association of Research Libraries (ARL) and Texas A\&M University (TAMU) which launched as a measure toolkit in 1999 (Pedramnia, Modiramani, \& Ghanbarabadi, 2012). "It was adapted from an instrument called SERVQUAL (for SERVice QUALity), which is grounded in the "Gap Theory of Service Quality" developed by the marketing research team of A. Parasuraman, V.A. Zeithaml, and L.L. Berry" (Blixrud, n.d., p. 1). As outlined by Brito and Verguei (2013), the goals of LibQUAL are to:

- Foster a culture of excellence in providing library service

- Help libraries better understand user perceptions of library service quality

- Collect and interpret library user feedback systematically over time

- Provide libraries with comparable assessment information from peer 
institutions

- Identify best practices in library service.

- Enhance library staff members' analytical skills for interpreting and acting on data.

In this study, the following three dimensions of LibQUAL model are adopted;

a. Affect of Service: this dimension is concerned with three service dimensions adopted from SERVQUAL. This include; (1) assurance; which relates to the knowledge and courtesy of employees and their ability to convey confidence and trust; (2) empathy, which relates to library staffs' ability to give individualized attention to customers; and (3) responsiveness, this refers to librarian's willingness to help customers and provide prompt service (Kamaruddin, Baharuddin, \& Mustaffar, 2014). Veasna and Nimol (2015, p.154) avers that affect of service "dimension is related to questions on user interactions with, and the general helpfulness and competency of library staff."

b. Library as Place: this concept borrows the tangibles dimention from SERVQUAL.As noted by Kamaruddin, Baharuddin and Mustaffar (2014), this dimension is concerned with the physical environment of the library as a place for individual study, group work, and inspiration. The library should be a quiet space for individual activities, library space that inspires study and learning, a comfortable and inviting location and a community space for study (Veasna \& Nimol, 2015).

c. Information Control: is related to the ability of the library to provide patrons with access to electronic resoures that can be accessed 24/7 beyond the library walls; and provision of modern equipment that allows for an easy access to needed information (Veasna \& Nimol, 2015). According to Kamaruddin, Baharuddin and Mustaffar (2014), library collections should be enough to serve the users and there must be no barrier to infromation access Furthermore, it is essential that users are able to find the required information in the format of their choice, in an independent and autonomous way (Veasna \& Nimol, 2015).

If these three dimensions are well implemented and used time and again to evaluate the quality of school library services, then school library services will be 
remodelled to meet the current needs of the users. As a result, the school library will achieve its goals of supporting the learning and teaching activities of its host parent. Consequently, students will have reliable, convinient and well equiped library where they can improve their information literacy skills, research to solev their academic problems and general life challenges. Provison of quality services to students will positively impact their academic performance, thus building a knowledge based community which will have positive input in economic development.

Gap in literature: as of October $30^{\text {th }} 2018$, the researcher's used the terms 'school library' and 'LibQUAL' to search on google, not even one article was retrieved pertaining to the use of LibQUAL model to assess the quality of library services in school libraries. Only articles on academic, college, university and research libraries were retrieved. This imply that school libraries are neglected yet they form the foundation of the students' education. Children should be introduced to the culture of reading at an early stage,therefore, a good library with quality services should be established in all primary, secondary and senior secondary school to enable students have access to quality information. As a way of influencing policy changes in the educational sector, studies should be conducted in school libraries using such model as the LibQUAL. This will give policy makers reliable information that influences changes and implementation of quality school libraries.

\section{Discussion of the proposed framework}

The proposed model for assessing school library quality (see Figure 2), suggests that policies and procedures should be the foundation for all library programs. It is an element that cuts across all LibQUAL dimensions. This is so, because every effective information management program should have a guiding policy in place to ensure efficiency and effectiveness of the management processes. According to IFLA School Libraries Section Standing Committee (2015, p.22), "a school library should be managed within a clearly structured policy framework that recognizes the library as a core resource and centre for reading and inquiry." IFLA guidelines also make it clear that the school library policy should be developed by the school librarian together with teachers and administrators. It is further noted that, the policy should specify the role of the library in relation to the following components:

- Formal and informal curriculum in 
the school

- Learning methods in the school

- National and local standards and criteria

- Learning and personal development needs of students

- Needs of teachers

- Raising levels of academic achievement

- Developing inquiry skills

- Promoting and motivating reading

- Open-mindedness and civic engagement (IFLA School Libraries Section Standing Committee, 2015) Thus, the school library policy should be the foundation for all school library services and management activities.

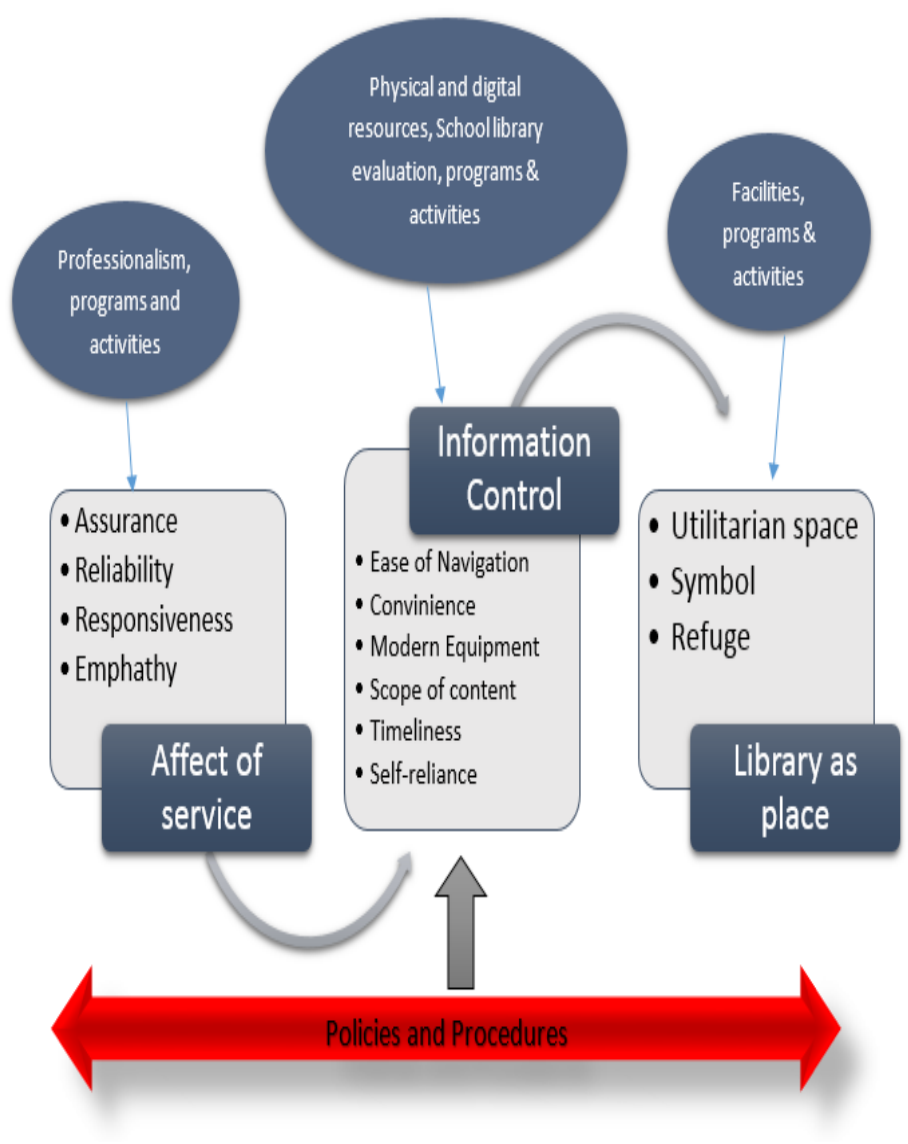

Figure 2: School library service delivery improvement framework.

Despite the significance of the school library policy, several studies have revealed that most governments, particularly in poor and developing African countries, do not have a school library policy (Latif, Ahmed, Satti, Satti, \& ul-Haq, 2018; Mojapelo, 2018; Paton-Ash \& Wilmot, 2015; Ramzan, n.d.;). These studies further revealed that school libraries were facing various challenges such as; unqualified library staff, lack of a proper functional library building, outdated information resources and unhealthy 
atmosphere which discourage the reading habits of the children. These problems maybe compelled by the lack of a school library policy. Thus, without a school library policy school library services will be hindered. Consequently inhibiting quality access to information by students. Khayelitsha (2015) argues that limited access to basic resources devalues the quality of education and limits learner achievement. Khayelitsha (2015) further revealed that learners in South Africa did not have access to basic quality education and consequently cannot access post school tertiary education and/or employment opportunities. As a result, there is high unemployment rate amongst the country's youth. High unemployment rate is a huge hindrance to attaining the SDGs. Therefore, it ought to be avoided by providing quality education and access to quality information. This can be made possible through the implementation of school library policies which will ensure that the right resources have been put into place.

The second element of the IFLA school library guidelines is 'proffessionalism, programs and activities' which is directly linked to Affect of service (Figure 2). "To be successful in fulfilling its educational mission, a school library must actively engage the educational community through well-researched programs of instructional and service activities" (IFLA School Libraries Section Standing Committee, 2015, p.38). This depicts that for school library staff to effectively render quality services to students, there must be well articulated programs in place that meet the information needs of the library users. Furtheremore, the library staff should meet a certain standard of proffessionalism for them to be able to satisfy the dimension of 'Affect of Service'. IFLA School Libraries Section Standing Committee (2015), states that, the instructional work of a qualified school librarian should focus on core activities, including:

- Literacy and reading promotion;

- Media and information literacy (e.g., information literacy, information skills, information competences, information fluency, media literacy, transliteracy, transmedia literacy);

- Inquiry-based learning (e.g., problem-based learning, critical thinking);

- Technology integration;

- Professional development for teachers; and

- Appreciation of literature and culture. 
The third element of the IFLA school library guidelines relates to "physical and digital resources, school library evaluation and programs'. This is directly linked to the 'Information Control' dimension of the LibQUAL model. "The facilities, equipment, and collections of a school library need to evolve in response to changes in the teaching and learning needs of the students and the teachers" (IFLA School Libraries Section Standing Committee, 2015, p32). This means that the library should be in a position to provide both digital and physical reources which are easily accessible to the library users. The school management should regualry use the evaluation forms provided by the IFLA school library guidelines to continously assess if the school library programs and activities meet the needs of the users. Librarians should asess if the current programs enable access to modern technology, if the services are convinient, if information is provided in timely manner and that students have the skills to independently access information effectively.

The last element of the IFLA school library guideline relates to 'facilities, programs and activities. It is directly linked to 'Library as Place' dimension of the LibQUAL (Figure 2). It simply means that for libraries to successfully provide satisfying and quality services to patrons, the library facilities must be welcoming, convinient and conducive for the users. The library facilities should have adeqaute signage and study areas for group work. Acccording to IFLA School Libraries Section Standing Committee (2015), the following considerations need to be included in planning school library facilities:

- Accessibility and proximity to teaching areas.

- Noise factors, with at least some parts of the library free from external noise.

- Appropriate and sufficient light, natural and/or artificial.

- Appropriate room temperature (e.g., air-conditioning, heating) to ensure good working conditions year round as well as the preservation of the collections.

- Appropriate design for library users with special needs.

- Adequate size to give space for the collection of books, fiction, nonfiction, hardback and paperback, newspapers and magazines, nonprint resources and storage, study spaces, reading areas, computer workstations, display areas, and 
work areas for library staff.

- Flexibility to allow multiplicity of activities and future changes in curriculum and technology.

If the IFLA school library guidelines are strictly adhered to, then it is possible to achieve the desired school library environement.

\section{Conclusion and recommendations}

The proposed model aims at improving school library services. Thus, if the model is adopted, it can be used to assess user's perspectives about the school library through the LibQUAL lens. As a way of verifying the user's perspectives, IFLA guidelines should be used to observe the library environment (programs and activities, staffing/professionalism, physical and digital resources and facilities). This combined model will help the school management to obtain feedback from both students, library staff and the teaching staff, unlike using LibQUAL only that will focus on the customer's perspectives only. The

\section{References}

Agyekum, B. O., \& Filson, C. K. (2012). The challenges of school libraries after the implementation of the new educational reforms in Ghana. Library Philosophy and Practice (ejournal)(932). Retrieved October 29, 2018,

from combined model provides a holistic and comprehensive view of the library service quality. The researchers thereby, suggest that empirical studies should be carried out using this proposed framework to assess the quality of school library services in developing countries. This will help the government to know the status of school libraries in developing countries and help policy makers to implement the right strategies that will enable school libraries to be part of the vehicles for achieving SDGs 2030. This combined assessment model is essential in implementing school library programs and services. Thus, further research is required to test if this proposed model will increase effectiveness in library services and there is need to develop a combined checklist that outlines the elements of the IFLA school library guidelines and those of the LibQUAL model.

https://digitalcommons.unl.edu/cgi/vi ewcontent.cgi $?$ article $=2282 \&$ context $=$ libphilprac

Ashikuzzaman, M. D. (2013). Functions of school library. Retrieved October 31, 2018, from Library and Information Science Network: http://www.lisbdnet.com/functions- 
of-school-library/

Blixrud, J. C. (n.d.). Evaluating library service quality: Use of LibQUAL+. Retrieved October 28, 2018, from libqual.org:

http://libqual.org/documents/admin/b lixrud.pdf

Boelens, H. (2012). What is a school library? : International guidelines. Retrieved October 31, 2018, from International Association of School Librarianship

(IASL):

https://indianschoollibraryassociation .files.wordpress.com/2012/10/sigresearch-school-libraryaugust2012.pdf

Brito, G. F., \& Verguei, W. C. (2013). Quality evaluation of academic library: The LIBQUAL methodology and its perspectives of implementation in Brazil. Brazillian Journal of Information Science, 2544.

Helgren, J., \& Lance, K. C. (2010). The impact of school libraries on student achievement: Exploring the school library impact studies. Retrieved February 25, 2019, from https://vimeo.com/album/1480129

IFLA School Libraries Section Standing Committee. (2015). IFLA school library guidelines. 2. (B. SchultzJones, \& D. Oberg, Eds.) Netherlands: International Federation of Library Associations and Institutions.
IFLA Trend Report. (2013). What is the IFLA trend report. Retrieved February 25, 2019, from https://trends.ifla.org/

Kamaruddin, N. A., Baharuddin, M. F., \& Mustaffar, M. Y. (2014). Assessment of service quality using LibQUAL+ Three Key dimensions tool at public libraries in Klang Valley, Malaysia. Vision 2020: Sustainable Growth, Economic Development, and Global Competitiveness- Proceedings of the 23rd International Business Information Management Association Conference, IBIMA 2014. 1, pp. 280-291. International Business Information Management Association, IBIMA.

Khayelitsha, T. (2015). Equal education: Daily challenges and solutions to running school libraries-the case of Bookery library project. Retrieved November 23, 2018, from DGMT Confluence of Ideas and Practice: http://www.dgmtcommunity.co.za/organisations/equal -education/learning-briefs/dailychallenges-and-solutions-runningschool

Latif, A., Ahmed, Z., Satti, N. A., Satti, M. H., \& ul-Haq, I. (2018). School libraries of Pakistan: A case study of government high schools in Tehsil Gujar Khan, Rawalpindi. Scholars Journal of Arts, Humanities and Social Sciences, 6(3), 552-557. 
doi:10.21276/sjahss.2018.6.3.12

Library Research Service. (2014). What is a school library? Retrieved October 31, 2018, from lrs.org: https://www.lrs.org/2014/01/06/scho ol-library/

Library Research Services. (2015). School libraries impact studies. Retrieved February 25, 2019, from https://www.lrs.org/datatools/school-libraries/impact-studies/

Mkumbo, W. C. (2016). The role of school libraries in realizing the achievement of inclusive and equitable quality education in Tanzania: SDGs by 2030. International Research: Journal of Library \& Information Science, 6(2), 184-190.

Mojapelo, S. M. (2018). Challenges in establishing and maintaining functional school libraries: Lessons from Limpopo Province, South Africa. Journal of Librarianship and Information Science, 50(4), 410-426. doi:10.1177/0961000616667801

Paton-Ash, M., \& Wilmot, D. (2015). Issues and challenges facing school libraries in selected primary schools in Gauteng Province, South Africa. South African Journal of Education (e-journal), 35(1). Retrieved October 28, 2018, from http://www.scielo.org.za/pdf/saje/v3 5n1/01.pdf

Pedramnia, S., Modiramani, P., \& Ghanbarabadi, V. G. (2012). An analysis of service quality in academic libraries using LibQUAL scale: Application oriented approach, a case study in Mashhad University of Medical Sciences (MUMS) libraries. Library Management, 33(3), 159-167. doi:10.1108/01435121211217144

Queensland Government. (2014). Role of the school library. Retrieved October 31, 2018, from http://education.qld.gov.au/library/su pport/role.html

Ramzan, M. (n.d.). Status of School Library Development in Pakistan. Sri Lanka Journal of Librarianship \& Information Management , 1(1), 2024.

Reed, D. (2016). Guidelines for prep school libraries. Retrieved February 25, 2019 , from https://www.sla.org.uk/dwl.php?doc =guidelines-for-prep-schoollibraries-final.pdf

Rehman, S. U. (2012). Understanding the expectations of Pakistani libraries users: A LibQUAL study. Library Philosophy and Practice (e-journal), Paper 372. Retrieved May 26, 2017, from http://digitalcommons.unl.edu/cgi/vi ewcontent.cgi $?$ article $=1806 \&$ context $=$ libphilprac

Rehman, S. U., Kyrillidou, M., \& Hameed, I. (2014). Reliability and validity of a modified LibQUAL+ ${ }^{\circledR}$ survey in 
Pakistan: An Urdu language experience. Malaysian Journal of Library \& Information Science, 19(2), 83-102.

School Library Association. (2016). The Purpose of a School Library. Retrieved October 31, 2018, from https://www.sla.org.uk/purpose-ofschool-library.php

Veasna, U., \& Nimol, C. N. (2015). "Effect of LibQUAL dimensions on library user satisfaction: Evidence from Cambodia. Journal of Business Administration and Management Sciences Research , 4(7), 152-165. Williams, D., Wavell, C., \& Morrison, K. (2013). Impact of school libraries on learning: Critical review of evidence to inform the Scottish education community. Aberdeen: Robert Gordon University.

\section{About the Authors}

\section{Liah Shonhe}

Liah Shonhe is a PhD candidate at Dalian University of Technology in China. She holds a Master's Degree in Archives and Records Management and a Bachelor Degree in Library and Information Studies. Her research interests are; knowledge/information management, mobile technologies, Agricultural data management, ICTs \& education, digital libraries, EDRMS, staff motivation, organizational culture, open data sharing, gender issues in information access and change management. Pertaining to work experience, Liah has been a teaching assistant at the University of Botswana for three academic years in the Department of Library and Information Studies and for one academic year at the Communication and Study Skills Unit. She is a member of the Records and Information Association in Botswana (RIAB) and the Botswana Library Association (BLA).

\section{Evelyn Mmaserame Marambe}

Evelyn Marambe is a Masters graduate in Library and Information Services at the University of Botswana and currently works as a Teacher librarian in a Secondary School. Her research interests are Information Management, and knowledge management, Information Literacy, Service quality in school libraries, ICTs \& education, and digital libraries. She has teaching experience in information literacy and communication \& presentation skills. 